\title{
Inhibition of luteolysis and embryo-uterine interactions during the peri-implantation period in pigs
}

\author{
A.J. Ziecik, A. Blitek, M.M. Kaczmarek, A. Waclawik and M. Bogacki
}

Institute of Animal Reproduction and Food Research of Polish Academy of Sciences, Tuwima 10, 10-747 Olsztyn, Poland

\begin{abstract}
Inhibition of luteolysis and establishment of pregnancy in pigs results from oestrogen secretion by the conceptuses and requires progesterone produced by the corpus luteum $(\mathrm{CL})$. An integral part of maternal recognition of pregnancy in the pig is the redirection of prostaglandin (PG) $F_{2 \alpha}$ secretion from endocrine (blood) to exocrine (uterus) direction and an increase of $\mathrm{PGE}_{2}$ synthesis in both the endometrium and conceptus. Uterine and conceptus $\mathrm{PGE}_{2}$ synthases play an integrated role in establishing the $\mathrm{PGE}_{2}: \mathrm{PGF}_{2 \alpha}$ ratio necessary for luteal maintenance. The luteolytic or luteotrophic changes in the $\mathrm{CL}$ are synchronised with the release of maternal pituitary and ovarian hormones. The presence of uterine oxytocin (OT) and luteinising hormone (LH) receptors are important for the luteolytic effect of $\mathrm{PGF}_{2 \alpha^{*}}$. Conceptus oestrogen secretion coincides with autocrine and paracrine dialogue between the multiple conceptuses and uterine biological compounds and their receptors in trophoblast and endometrium.
\end{abstract}

\section{Introduction}

In pigs, the period from successful fertilisation to the process of initiation of implantation lasts about 14 days. Biochemical endometrial-blastocyst interactions occur by Day 11 of pregnancy (Bazer et al., 1982). During this time some form of embryonic signalling is necessary not only for maternal recognition of pregnancy but also to prepare the uterine environment for implantation.

In the absence of fertilised ova and blastocyts endometrial secretion is limited to the period between the mid to late luteal phase of the oestrous cycle. This secretory activity is dependent upon maintenance of functional corpora lutea $(\mathrm{CL})$. In the pig, as in other species, $\mathrm{PGF}_{2 \alpha}$ is the major signal for luteolysis. In order to maintain luteal function in early pregnancy, the effects of the uterine luteolysin are prevented. Recent concepts as to how this is brought about are presented in this review. An alternation of luteolytic or luteotrophic changes in the ovary are synchronised with secretion of pituitary/hypothalamus and ovarian hormones.

The developmental changes of embryos before implantation are dependent on biological molecules secreted by the endometrium and conceptuses. The aim of such maternal-conceptus dialogue is the synchronisation of blastocyst development with the preparation of the uterus for 
implantation. Biological molecules facilitating embryo-uterine cross talk include growth factors, cytokines, adhesion molecules, pregnancy-associated proteins, prostaglandins and hormones. The length of the article is limited and this review does not cover the role of cytokines, adhesion molecules and proteinases in the establishment of pregnancy. Some functions of these compounds have been previously reviewed (Lessey, 2002; Schäfer-Somi, 2003; Spencer and Bazer, 2004; Szafranska et al., 2004).

\section{Hormones}

\section{Oestradiol}

Pig conceptuses begin to produce oestrogens on Day 11 of pregnancy (Geisert et al., 1982). The pattern of release is biphasic, with increased secretion on Day 12 and Days 23-30 of pregnancy (Bazer et al., 1982). It is generally believed that the luteotrophic effect of oestrogen in pigs is both indirect, resulting from a reduced uterine release of $\mathrm{PGF}_{2 \alpha}$ into peripheral circulation, and direct (Conley and Ford, 1989). Oestradiol also maintains high $\mathrm{LH}$ receptor levels both in the $\mathrm{CL}$ (Garverick et al., 1982) and uterus (Ziecik et al., 1992).

Interestingly, no differences in oestrogen receptor (ER) mRNA expression were found between cyclic and pregnant pigs on Days 10-15 after oestrus (Geisert et al., 1993). In the same studies, immunocytochemical staining of ER in the luminal (LE) and glandular epithelium (GE) was readily detectable on Day 12 of pregnancy but reduced on Day 15. The intensity of ER staining in porcine endometrium was most prominent in deep lying glands (Sukjumlong et al., 2004). Changes in endometrial ER expression are consistent with a physiological role for oestrogens produced by the conceptus in the maternal recognition of pregnancy in the pig.

\section{Progesterone}

The establishment of normal endometrial receptivity appears to be associated with the downregulation of epithelial progesterone receptors that coincides with the time of embryo implantation (Spencer and Bazer, 2002). In all mammalian uteri, progesterone receptors are expressed in the endometrial epithelium and stroma during the early luteal phase. Long exposure of the endometrium to progesterone negatively autoregulates progesterone receptor expression in the endometrial epithelium (Geisert et al., 1994). In rodent, human and primate uterus progesterone regulates a number of genes including transcription factors, growth factors, homeobox genes and enzymes (Gray et al., 2001). In pigs, progesterone increases expression of integrins $\alpha 4, \alpha 5$ and $\beta 1$ during the peri-implantation period, which may in part define the implantation window in this species (Burghardt et al., 2002).

\section{Oxytocin (OT)}

In ruminants, OT from the CL binds to uterine OT receptors to elicit pulses of PGF $2 \alpha^{\prime}$ but this mechanism is not well-defined for pigs (Ziecik, 2002). The porcine CL synthesises OT, although to a lesser extent than in ruminants (Choy and Watkins, 1988). The increase in circulating concentrations of OT during luteolysis is associated with an elevation in uterine secretion of PGF $_{2 \alpha}$ (Kotwica et al., 1990). Moreover, exogenous OT stimulates PGF ${ }_{2 \alpha}$ secretion in cyclic and early pregnant pigs (Carnahan et al., 1996). Whiteaker et al. (1994) proposed that OT binds to its endometrial receptors and utilises the phosphoinositide pathway to initiate luteolytic secretion of $\mathrm{PGF}_{2 \alpha}$ in the pig. The low concentration of OT receptors in the endometrium of early pregnant pigs (Okano et al., 1996) could indicate that this suppression is an important component of the mechanism of the recognition of pregnancy in the pig. However, Ludwig et al. (1998) did not support the hypothesis that endometrial responsiveness to OT is regulated by the amount of OT receptors in swine, but rather with the level of OT receptors coupling to $G$ protein and phospholipase $C$ pathway. 
The question of whether OT causes $\mathrm{PGF}_{2 \alpha}$ release in intact gilts remains open, since agreement between OT and PGFM peaks is only about $30 \%$ and blocking of OT receptors neither prevents luteolysis nor changes the duration of the oestrous cycle in swine (Kotwica et al., 1999). It may suggest that OT is not mandatory to induce endometrial release of $\mathrm{PGF}_{2 \alpha^{\circ}}$

\section{Luteinising hormone (LH)}

An early report by Du Mesnil du Buisson and Legise (1963) suggested that after an initial LH trigger, the porcine CL can function without pituitary support until Day 12 of the oestrous cycle. However, passive immunisation of the gilt with anti-pLH serum on Day 8 of the oestrous cycle dramatically inhibited progesterone secretion (Szafranska and Ziecik, 1989). Inhibition of LH secretion with $\mathrm{GnRH}$ antagonist during the early luteal period reduces $\mathrm{CL}$ size and progesterone production (Brussow et al., 2001). These data indicate that during the oestrous cycle the porcine $C L$ appears not as autonomous as was believed earlier (Bazer et al., 1982). The porcine uterus, including the endometrium, possesses $\mathrm{LH}$ receptors (Ziecik et al., 1986). The appearance of relatively high amounts of $\mathrm{LH}$ receptors in the endometrium coincides with the increase of $\mathrm{PGF}_{2 \alpha}$ secretion and perhaps with the down-regulation of progesterone receptors. Following the initiation of luteolytic $\mathrm{PGF}_{2 \alpha}$ secretion on Days 14-16, LH receptors decline in the endometrium. LH up-regulates COX2 protein expression and $\mathrm{PGF}_{2 \alpha}$ secretion from endometrium in vitro (Stepien et al., 1999). Furthermore, the systemic infusion (Ziecik et al., 2001) or intra-muscular injection of hCG (Guthrie and Bolt, 1983) induces PGF $_{2 \alpha}$ release in vivo. It seems that a window of endometrial responsiveness to $\mathrm{LH}$ in vivo falls within the period between Days 15 and 17 of the oestrous cycle. Additionally, there is a much higher correlation between LH and PGFM peaks (75.5\%; Ziecik et al., 2001) than between OT and PGFM (30\%; Kotwica et al., 1999).

The uterine $\mathrm{LH}$ receptors may also be involved in the maintenance of early pregnancy in the pig, since $\mathrm{LH}$ induced $\mathrm{PGE}_{2}$ release from endometrium on Days 14-16 of the oestrous cycle (Blitek and Ziecik, 2005) or early pregnancy (Ziecik et al., 2000). Moreover, LH in contrast to OT, affects secretion of the known angiogenic factor vascular endothelial growth factor (VEGF) from endometrial cells in culture (M.M. Kaczmarek, A. Blitek, D. Schams, A.J. Ziecik, unpublished).

\section{Prolactin (PRL)}

The function of PRL in the maintenance of pregnancy in the pig has not been completely defined (Dusza and Tilton, 1990). Circulating concentrations of PRL in early pregnancy do not differ from the basal concentrations during the oestrous cycle (Dusza and Krzymowska, 1981). It was suggested that PRL cooperates with oestrogen in the exocrine secretion of PGF ${ }_{2 \alpha}$ during establishment of pregnancy in pigs (Gross et al., 1990). Since administration of oestrogen to Day 11 cyclic gilts up-regulates endometrial PRL receptors and a significant increase in the number of these receptors was observed in the Day 12 pregnant uterus (Young et al., 1990), PRL may also play a role in maternal recognition of pregnancy. However, administration of PRL during the luteal phase of the oestrous cycle in gilts had no effect on the basal levels of progesterone or oestradiol (Dusza et al., 1986).

\section{Growth factors}

Insulin-like growth factors (ICFs)

The IGFs are implicated in the control of proliferation and differentiation of the uterus in preparation for blastocyst implantation and during later foeto-placental development. In pigs, endometrial IGF-I mRNA was detected on Days 8-14 of pregnancy (Letcher et al., 1989) and IGF-II mRNA after implantation (Simmen et al., 1992). Thus, in the porcine uterus IGF-I, rather than IGF-II, appears to dominate in early pregnancy (Table 1). 


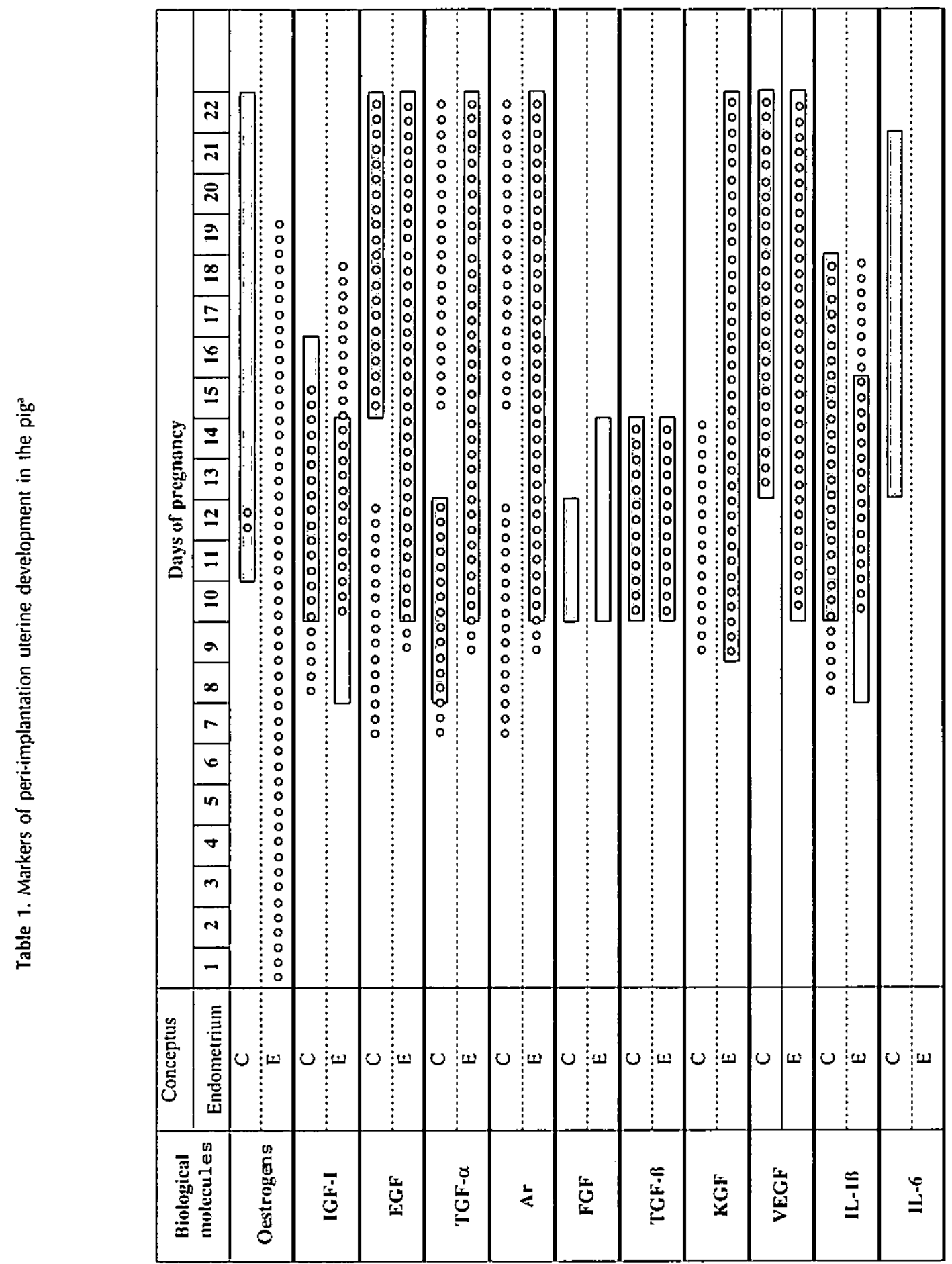

Abbreviations used: $C$, conceptus; $E$, endometrium; IGF-I, insulin-like growth factor; EGF, epidermal growth factor; TGF- $\alpha$, TGF- $\beta$, transiorming growth factor $-\alpha$ and $-\beta ;$; $A$, amphiregulin; KCF, keratinocyte growth factor; FCF, fibroblast growth factor; VECF, vascular endothelial growth factor; IL-1B, IL-6, interleukins - 1B and -6; IFN- $\alpha$, IFN- $\delta$, IFN- $\gamma$, interferons $-\alpha,-\delta$ and $\gamma$, LIF, leukemia inhibitory factor; OPN, osteoponin; MUC-1, MUC-4, 


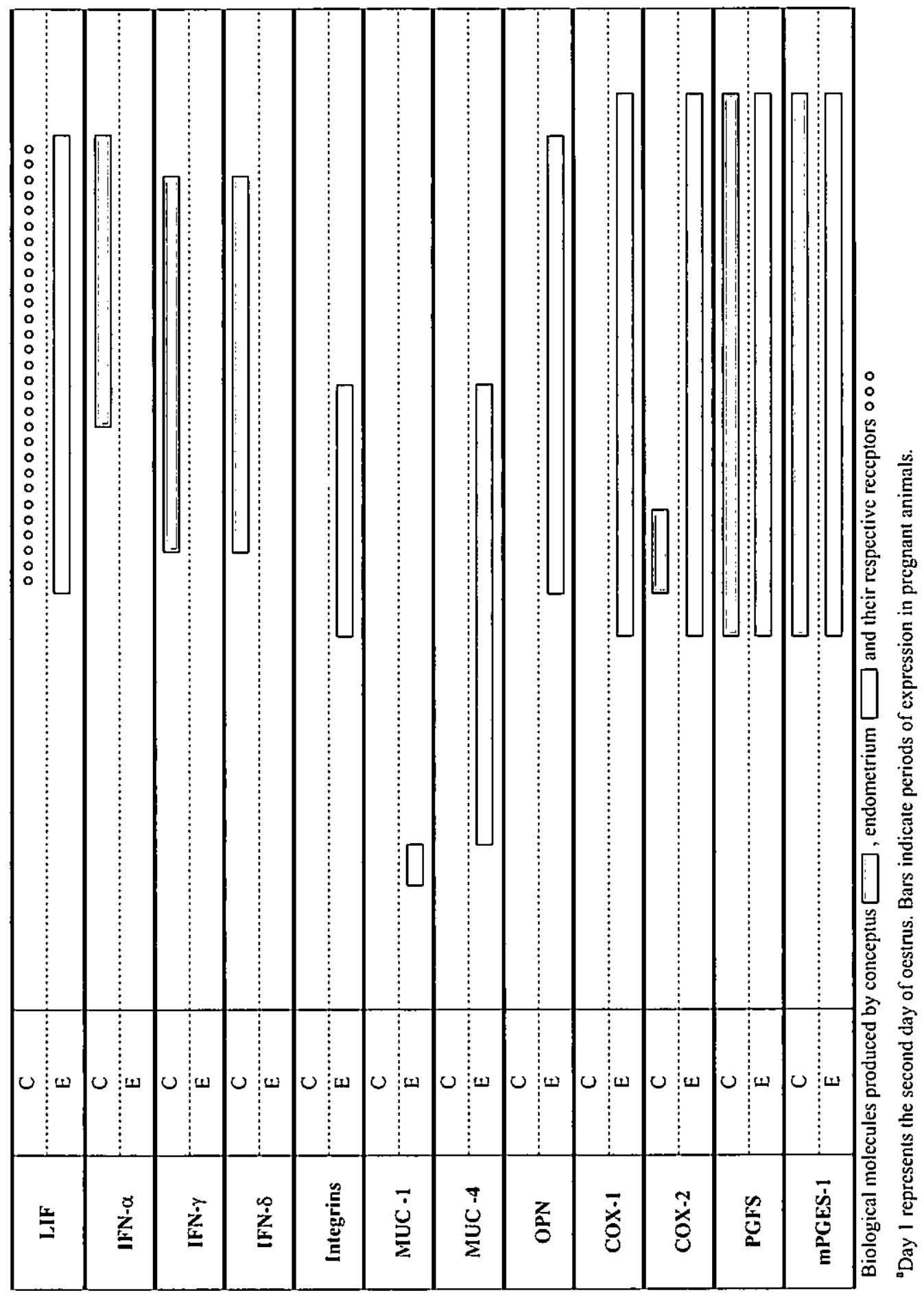

mucosins -1 and -4 ; COX-1, COX-2, cyclooxygenases -1 and -2; PGFS, PGF synthase; mPGES-1, microsomal PGE synthase-1. The presence of markers and receptors is based on the available literature. The absence of markers or receptors indicates that they have not yet been measured, or that they have been studied and not found 
The endometrial expression of IGF-I mRNA and secretion of IGF-I peptide into the uterine lumen peaks at Day 12 of pregnancy, concomitant with maximal oestrogen production by the conceptuses (Simmen et al., 1989; 1992). Moreover, densities of immunoreactive $\mathrm{P}_{450}$ in porcine conceptuses were highly correlated with the ratio of IGF-I/IGF-II in the uterine lumen (Ko et al., 1994). A role for IGF-I in conceptus development is supported by the presence of IGF-I receptor mRNA in the peri-implantation porcine blastocyst (Green et al., 1995).

In blood and other extracellular fluids IGFs are complexed to specific binding proteins (IGFBP). In human, IGFBP-1 is the major IGFBP of the endometrium and decidua. In the pig, however, IGFBP-1 mRNA was not detected in porcine endometrium. Of the five IGFBP genes found in the uterus of pregnant pigs, only IGFBP-2 exhibited obvious tissue-specificity of expression. This protein was localised in GE and LE, with much greater intensity of immunostaining during midthan early pregnancy. Also IGFBP-2 mRNA expression was higher after the implantation period (Days 30-60; Song et al., 1996).

In the pig, uterine luminal flushings collected on Days 10 and 11 of gestation contain several IGFPBs, with IGFBP-3 being most abundant. By day 12, however, IGF8Ps were substantially diminished or undetectable. Examination of the morphology of flushed conceptuses showed that the loss of ICFBPs in uterine fluid was associated with the transition from spherical to filamentous forms. Since the concentration of IGFBP-3 mRNA in endometrial tissue was not altered in a similar way, it may indicate that the lack of IGFBP-3 in filamentous conceptuses is a result of proteolysis rather than decreased expression of IGFBP-3 gene. Thus, elongating porcine conceptuses induce IGFBP protease activity, which may increase the intrauterine bioavailability of IGFs (Lee et al., 1998).

\section{Epidermal Growth Factors (ECFs)}

The EGF family includes EGF itself, transforming growth factor- $\alpha$ (TGF $\alpha$ ), heparin binding EGFlike factor (HB-EGF) and amphiregulin (Ar). All of these molecules bind to the same cell surface tyrosine kinase receptor (Prigent and Lemoine, 1992). The possible function of EGFs during pregnancy is to stimulate embryonic growth and development.

Porcine embryos possess EGF receptors (EGF-R) as indicated by their binding of labelled EGF (Corps et al., 1990). Moreover, EGF-R mRNA has been demonstrated in both pre-and post-elongation blastocyst (Days 7-12 and 15-22, respectively). On the other hand, EGF mRNA expression is limited to postelongation conceptuses. EGF is present predominately in the embryo and amnion (Vaughan et al., 1992). Since the amnion synthesises $P G E_{2}$ and $P G E_{2}$ concentration in amniotic fluid increases as pregnancy progresses, it is possible that endogenous EGF may regulate $P G E_{2}$ synthesis by the amnion. TGF $\alpha$, which has significant sequence homology to EGF, was detected only in the developing blastocyst at Days 8-12, with the highest mRNA levels at Day 10 . Since the porcine blastocyst begins to elongate from Day 10.5 of pregnancy (Stroband and Van der Lende, 1990), TGF $\alpha$ may be involved in the complex developmental reorganisation of the conceptus.

EGF-R in the porcine uterus was detected on Day 13 of pregnancy and the binding capacity of labelled EGF was higher (5-fold) for stromal, than for glandular epithelial cells (Zhang et al., 1992). Endometrial EGF-R mRNA expression was lowest on Day 10 of pregnancy and increased significantly from Days 12 to 22. EGF, TGF $\alpha$ and Ar are also present in the porcine endometrium, but with different patterns of expression. EGF mRNA level was similar on all days of pregnancy studied (Days 10-22), but TGF $\alpha$ and Ar mRNA concentrations were increased on Day 12 of pregnancy (Kennedy et al., 1994).

Fibroblast Growth Factors (FCFs)

FGFs are structurally related proteins able to stimulate fibroblast proliferation. FGFs may also 
influence cell differentiation, matrix formation and cell movement. These peptides affect extracellular matrix deposition, which is important for embryonic development, suggesting that FGFs could be critical for embryogenesis (Baird and Böhlen, 1991).

In pigs, the presence of acidic and basic FGF (aFGF and bFGF respectively) was studied in conceptuses and uterine endometrium on Days 10-14 of pregnancy (Gupta et al., 1997). Differential expression of both aFGF and bFGF was observed according to pregnancy status. Positive immunostaining for bFGF was shown in both LE and GE and in stromal cells of uterus, with stronger positive staining from Day 12. This pattern of bFGF expression could be an effect of conceptus-derived oestrogens. The intense immunostaining for bFGF was also localised in cells on the embryonic disc and visceral endoderm on Days 10 and 11 . Mesoderm cells were positively stained for bFGF on Days 11-12 of pregnancy. Acidic FGF was localised only in stromal cells of porcine endometrium. These data indicate that bFGF, but not aFGF, may directly influence the development and/or differentiation of porcine conceptuses (Gupta et al., 1997). Moreover, FGF peptides were extracted from porcine uterine tissues and luminal fluids during early pregnancy (Brigstock et al., 1989).

\section{Transforming growth factor (TCF) B}

The regulatory roles of TGFß in the uterus during pregnancy include decidualisation, apoptosis, trophoblast attachment, growth, invasion and differentiation, immunotolerance, cytokine and hormone production and embryogenesis (Godkin and Doré, 1998). During early pregnancy in pigs, mRNA expression for TGFß 1,2 and 3 increases progressively in LE and underlying stroma from Days 10 to Day 12 (2-fold) and from Day 12 to Day 14 (4-fold; Gupta et al., 1998a). TGFß proteins were also localised in uterine tissues during pregnancy and the pattern of protein expression was similar to mRNA for TGFß (Gupta et al., 1998b). The increased uterine TGFß expression may be due to the effect of conceptus-secreted oestrogens.

The concentration of TGFB receptors (type I and II) in porcine uterine tissue was also dependent on the day of pregnancy. Immunostaining for both receptors was very weak on Days 10 and 11 and detected only in apical membranes of LE and GE, but later (Days 12-14 of gestation) the intensity of staining increased and was present in both membranous and cytoplasmic components of the epithelial cells (Gupta et al., 1998b).

Porcine conceptuses express mRNA and immunoreactive protein for both TGFß and TGFß-R, indicating that they are not completely dependent on a maternal source of TGFß (Gupta et al., 1996; 1998b).

Bioactive TGFß at the conceptus-maternal interface may be associated with conceptus attachment. In pigs, active forms of TGFß were detected in luminal fluid on Days 12-14, but not on Days 10 and 11 of gestation (Gupta et al., 1998b). Additionally, TGFß was shown to stimulate extracellular matrix proteins like fibronectin, collagens, proteoglycans, and their integrin receptor subunits (Roberts et al., 1990).

\section{Keratinocyte growth factor (KCF)}

Keratinocyte growth factor/fibroblast growth factor-7 (KGF/FGF-7) is a paracrine mediator of epithelial-mesenchymal interactions in the female reproductive tract. In the pig, however, KGF is expressed predominantly in the endometrial epithelium (Ka et al., 2000). KGF mRNA was detected in the endometrium throughout pregnancy with very high levels on Days 12-15. Messenger RNA concentrations were about 3-fold higher on Day 12 of gestation in comparison to Day 12 of the oestrous cycle. Receptors for KGF (KGF-R) were localised only in LE and GE of porcine endometrium. The trophectoderm of conceptuses also expresses KGF-R, but not KGF. These data suggest that in the pig, which has a diffuse, epitheliochorial placentation, KGF 
may play a role in paracrine epithelial-epithelial interactions between conceptus and uterus during early pregnancy (Ka et al., 2000). Moreover, the expression of uPA (a marker of differentiation) in pig conceptuses was stimulated by KGF, suggesting that KGF affects trophectoderm cell differentiation (Ka et al., 2001).

\section{VEGF ligand-receptor system}

Expression of VECF ligand-receptor system in the $C L$ during luteolysis

Cyclic changes of vascularity in the $\mathrm{CL}$ are tightly regulated by several angiogenic factors among which vascular endothelial growth factor (VEGF) seems to play a paramount role. Previous results indicate constant expression of VEGF mRNA in the porcine CL. However VEGF receptor (VEGFR) populations vary during the cycle, with reports of high levels of VEGFR-1 and low levels of VEGFR-2 during luteolysis (Boonyaprakob et al., 2003). Recently, we have evaluated in detail the mRNA and protein expression of VEGF, VEGFR- 1 and VEGFR-2 in the porcine $\mathrm{CL}$ during the oestrous cycle (Kaczmarek et al., 2005). Interestingly, mRNA and protein expression of VEGF and its binding sites decreased as luteolysis progressed. Therefore, taking account of other physiological features of luteolysis in pigs such as increasing PGF Pa $_{2 \alpha}$ secretion and gradual dissolution of small blood vessels in the $\mathrm{CL}$, our results suggest that the VEGF ligand-receptor system may be regulated by $\mathrm{PGF}_{2 \alpha}$ during $\mathrm{CL}$ regression. Recent results show a sharp decrease of VEGF $\mathrm{mRNA}$ and protein concentrations after $\mathrm{PGF}_{2 \alpha}$ induced luteolysis in mares (Al-zi'abi et al., 2003) and cows (Neuvians et al., 2004), suggesting that PGF ${ }_{2 \alpha}$ may be responsible for cessation of VEGF support for the luteal vasculature during luteolysis.

On the other hand, when pregnancy occurs, the lifespan of the CL must be extended to maintain pregnancy to term. Sufficient $\mathrm{CL}$ vascularity appears essential for the maintenance of luteal function, such as progesterone production during gestation. Our recent results show relatively high protein and mRNA levels of VEGF and its receptors in CL from pregnant pigs, which were comparable with mid-luteal phase and significantly higher than in regressed $\mathrm{CL}$ (Kaczmarek et al., 2005). It seems that extension of the luteal vascular lifespan during gestation in the pig is connected with prolonged survival and stabilisation of vessels that maintain $\mathrm{CL}$ function and structure for longer than in the non-fertile cycle.

\section{Expression and control of VECF expression in endometrium}

An important stage in embryo implantation in all mammals includes the close apposition of the foetal and maternal blood supplies. For this connection to occur there must be dramatic growth and remodelling of the endometrial vasculature (Lee and DeMayo, 2004). The uterine expression of VEGF has been well characterised in a number of animal models, and it is tempting to suggest that VEGF may be important for the establishment of sufficient vascular sheath within the endometrium during pregnancy. VEGF ligand-receptor system expression was localised in GE and LE of the gravid and non-gravid porcine uterus (Winther et al., 1999). Recently, we have observed increased protein levels of VEGF in the porcine endometrium before ovulation and in early luteal phase that suggests an important role of VEGF in the development and remodelling of uterine vasculature before implantation in pigs (Kaczmarek et al., 2004).

IGF-I and relaxin (RLX) stimulate VEGF secretion by porcine endometrial stromal cells obtained on Days 10-12 of pregnancy (M.M. Kaczmarek, A. Blitek, D. Schams, A.J. Ziecik, unpublished). The stimulating action of RLX on VEGF expression has already been demonstrated in human endometrial cells (Palejwala et al., 2002). Therefore it is possible that both IGF-I and RLX, may play an important role in angiogenesis and the maintenance of vascular 
function during implantation and placentation in pigs. Furthermore, we observed that LH may also stimulate VEGF output from porcine endometrial stromal cells in vitro (M.M. Kaczmarek, A. Blitek, D. Schams, A.J. Ziecik, unpublished), however its action was not as strong as in the case of IGF-I and RLX.

\section{Prostaglandins (PGs)}

Prostaglandins are key mediators of several female reproductive functions including ovulation, fertilisation, implantation and parturition. Cyclooxygenases (COX-1 and COX-2) convert arachidonic acid into $\mathrm{PGH}_{2}$, the common precursor of various forms of prostaglandins, including $\mathrm{PGE}_{2}$ and PGF $_{2 \alpha^{*}}$. The downstream enzymes, PGE synthase (PGES) and PGF synthase (PGFS), catalyse the transformation of $\mathrm{PGH}_{2}$ to $\mathrm{PGE}_{2}$ and $\mathrm{PGF}_{2 \alpha^{\prime}}$ respectively (Smith and Dewitt, 1996). $\mathrm{PGE}_{2}$ can be also converted to $P \mathrm{PF}_{2 \alpha}$ by $P \mathrm{PGE}_{2}-9$-oxoreductase. There are three forms of $\mathrm{PGES}$, among them microsomal PGES-1 (mPGES-1), a highly inducible form, along with COX-2 (Thoren et al., 2003). Prostaglandins are thought to be critical for establishment of pregnancy in the pig, since inhibition of prostaglandin synthesis results in pregnancy failure (Kraeling et al., 1985). In pigs, prostaglandins reach the $C L$ by a combination of both local and/or systemic mechanisms (Flint et al., 1982). The major luteolysin in pigs is $\mathrm{PGF}_{2 \alpha}$. Administration of $\mathrm{PGF}_{2 \alpha}$ in vivo initiates luteal regression and reduces serum progesterone concentration, but only after Day 12 of the oestrous cycle (Krzymowski et al., 1978). The mechanism of insensitivity of early porcine CL to exogenous $\mathrm{PGF}_{2 \alpha}$ was partially explained by Gadsby et al. (1990), who found that the number of $\mathrm{PGF}_{2 \alpha}$ high affinity receptors was low on Days 6-8, increased gradually up to Day 12 , then increased dramatically on Day 13 and remained high on Days 14-17. A change in direction of $\mathrm{PGF}_{2 \alpha}$ secretion is the basis of the 'endocrine versus exocrine' theory of maternal recognition of pregnancy in the pig (Bazer and Thatcher, 1977). These authors proposed that secretion of $\mathrm{PGF}_{2 \alpha}$ in non-pregnant animals during the mid- to late-luteal phase of the oestrous cycle is directed primarily toward uterine venous drainage (endocrine direction). This hypothesis was supported by the observation that $\mathrm{PGF}_{2 u}$ concentration in utero-ovarian vein is highest between Days 13 and 17-18 of the oestrous cycle, i.e. when events leading to luteolysis are initiated, while its accumulation in the uterine lumen during the oestrous cycle is low (Bazer et al., 1982). In non-pregnant pigs $\mathrm{PGF}_{2 a}$ and some components of histotroph, e.g. uteroferrin, move towards the endometrial stroma (endocrine direction) during the period of CL regression. PGF $_{2 \alpha}$ is secreted into the uterine venous system and transported, possibly by counter-current exchange, to the ovarian artery and the $\mathrm{CL}$, where it exerts its luteolytic effect. In pregnant gilts, however, there were no significant changes in utero-ovarian vein $\mathrm{PGF}_{2 \alpha}$ concentrations between Days 12 and 25 of pregnancy but the number of $P G F_{2 \alpha}$ peaks and their frequency were higher in non-pregnant gilts.

Krzymowski et al. (1990) and Stefanczyk-Krzymowska et al. (1990) suggested that the mechanism of $C L$ protection is based on the uptake of $P G F_{2 \alpha}$ originating from the uterus by the mesometrium. Then, $P G_{2 a}$ is transferred to the uterus in arterial blood by retrograde transfer (via the counter current system; Fig. 1). It has been suggested that the retrograde transfer of $\mathrm{PGF}_{2 \alpha}$ from uterine venous to arterial vessels and then to the uterine lumen may strongly reduce the peak concentrations during the pulsatile release of $P G F_{2 \alpha}$ from the uterus. Furthermore, the high $\mathrm{PGF}_{2 \alpha}$ concentrations found in the uterine lumen during early pregnancy (Bazer and Thatcher, 1977; Stefanczyk-Krzymowska et al., 1990) could also be a consequence of $\mathrm{PGF}_{2 \alpha}$ uptake from arterial blood supplying the uterus and removal into the uterine lumen. 


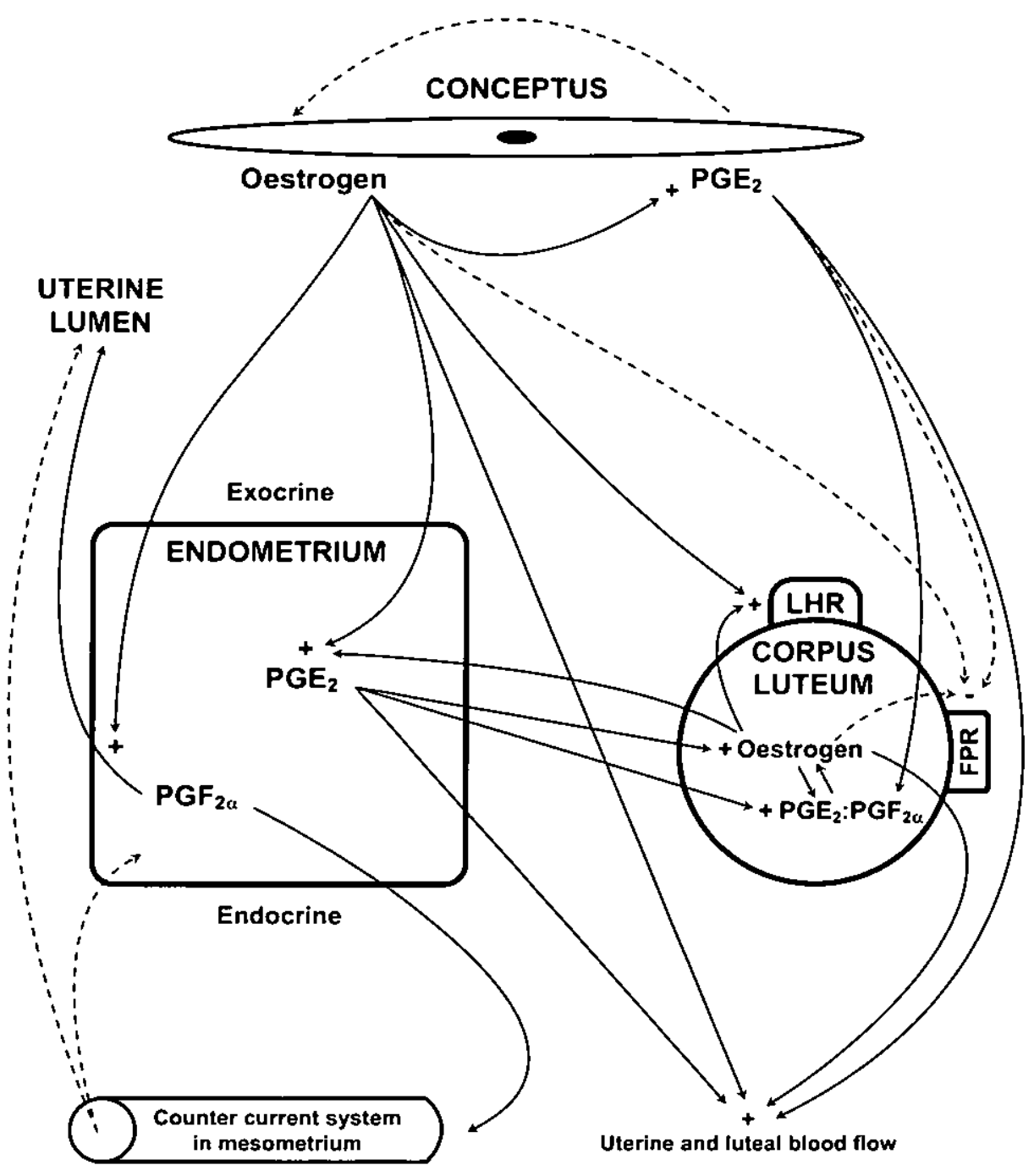

Fig. 1 Inhibition of luteolysis in pigs - a recent integrated concept. Oestrogens produced by the conceptus provide the first signal for establishment of pregnancy altering the direction of $\mathrm{PGF}_{2 \alpha}$ from endocrine to exocrine. Additionally, $\mathrm{PGF}_{2 a}$ of uterine origin is taken up by the mesometrium and transferred to the uterus in arterial blood by the counter current system operating in the broad ligament of the uterus. Oestrogens also cause $\mathrm{PGE}_{2}$ secretion by endometrium and conceptus to predominate (up-regulation of $\mathrm{PGE}_{2}$ synthase and possible inhibition of $\mathrm{PGE}_{2}-9$-oxoreductase) by changing $\mathrm{PGE}_{2}: \mathrm{PGF}_{2 \alpha}$ ratio, which is crucial for protection of the $C L$ from the luteolytic actions of $\mathrm{PGF}_{2 a}$. A putative feedback loop exists between oestrogen secretion by conceptus and $\mathrm{CL}$, and $\mathrm{PGE}_{2}$ release from conceptus, endometrium and $\mathrm{CL}$. The elevated $\mathrm{PGE}_{2}: \mathrm{PGF}_{2 \alpha}$ ratio increases oestradiol production by luteal cells, which serves as an additional source of oestrogens. Oestrogens also maintain $\mathrm{LH}$ receptors in the $\mathrm{CL}$ and have a direct luteotrophic effect and, together with $\mathrm{PGE}_{2^{\prime}}$ ensure the proper blood flow to endometrium and the CL. Finally, we propose that a conceptus product (oestrogen, $\mathrm{PGE}_{2}$ or other) acts on the $\mathrm{CL}$ to reduce the concentrations of $\mathrm{PCF}_{2 \alpha}$ receptors (Gadsby et al., 1993), providing an added level of luteal protection. This figure was modified from Ziecik (2002) and Spencer and Bazer (2004). 
A luteotrophic/antiluteolytic effect of $\mathrm{PGE}_{2}$ in the pig has been demonstrated (see review: Ziecik, 2002). The failure of attempts to maintain luteal function with intra-uterine infusions of $P G E_{2}$ in cyclic gilts could be a consequence of its conversion to $\mathrm{PGF}_{2 \alpha}$ (Okrasa et al., 1985). During the oestrous cycle pulsatile secretion of PGF ${ }_{2 \alpha}$ increased markedly on Day 13 and continued to increase through Days 16-18 (Christenson et al., 1994; Kotwica et al., 1999). The secretion of $\mathrm{PGE}_{2}$ also increases from Day 13 to 16 of the oestrous cycle but remains threefold lower than $\mathrm{PCF}_{2 \alpha}$ (Christenson et al., 1994). In contrast, prostaglandin secretion in mated gilts peaked earlier (Day 11-12) with $\mathrm{PGE}_{2}$ being the predominant eicosanoid. Furthermore, according to Christenson et al. (1994), concentrations of $\mathrm{PGE}_{2}$ were higher in utero-ovarian venous blood draining the gravid compared with the non-gravid uterine horn, and the ratio of secreted PGE:PGF is increased in harvested stromal cells from endometrium of pregnant pigs compared to cyclic gilts (Zhang and Davis, 1991).

In the pig, COX-1 and COX-2 were localised in the uterine stromal and epithelial cells. Quantification of COX-2 mRNA and protein expression revealed a significant increase at the time of luteolysis. In pregnant gilts, endometrial mRNA and protein concentrations of COX-2 were upregulated at the time of implantation (A. Blitek, A. Waclawik, M.M. Kaczmarek, A.J. Ziecik, unpublished). Thus, COX-2 seems to be involved in elevated prostaglandin production at the time of luteolysis and during implantation in pregnant animals.

The terminal prostaglandin synthases PGFS and PGES have been most studied in the bovine species (Arosh et al., 2004). Since porcine PGFS and mPGES-1 transcripts had not been previously characterised, we have recently cloned their CDNAs and found them to be highly similar to known mammalian homologues (Waclawik et al., 2004). Our studies on endometrial expression of PGFS throughout the oestrous cycle and early pregnancy indicate a potential role of PGFS in regulation of luteolysis in the pig. We also detected modulation of mPGES-1 mRNA and protein concentrations in porcine endometrium during the oestrous cycle and early pregnancy. High expression of mPGES-1 in endometrium before implantation may be involved in the change of $\mathrm{PGE}_{2}: \mathrm{PGF}_{2 \alpha}$ ratio necessary for maternal recognition of pregnancy. Another enzyme able to change the proportion of $\mathrm{PGE}_{2}: \mathrm{PGF}_{2 \alpha^{\prime}}$ is $\mathrm{PGE}_{2}-9$-oxoreductase converting $\mathrm{PGE}_{2}$ to $\mathrm{PCF}_{2 \alpha^{\prime}}$. Until now, control of $\mathrm{PGE}_{2}-9$ oxoreductase activity in porcine endometrium and placenta has not been studied extensively.

$\mathrm{PCE}_{2}$ alone increased, but $\mathrm{PGF}_{2 \mu}$ decreased, progesterone secretion by luteal cells (Gregoraszczuk and Michas, 1999). Treatment of cells collected from regressing CL with $\mathrm{PGE}_{2}$ and $\mathrm{PGF}_{2 u}$ in ratio $2: 1$ and 4:1 increased oestradiol production. Thus, oestradiol released under the influence of $\mathrm{PGE}_{2}$ by luteal cells may serve as an additional source of oestradiol to blastocysts during early pregnancy in the pig. It also supports an earlier suggestion that oestradiol has a direct luteotrophic effect in the pig (Conley and Ford, 1989). Pig conceptuses have tremendous prostaglandin synthetic ability (Geisert et al., 1982; Rosenkrans et al., 1992). Wilson et al. (2002) showed, for the first time, that COX-2 expression is developmentally regulated during elongation of porcine conceptuses. COX2 was not expressed in spherical or transitional conceptuses, but was up-regulated by the time a conceptus reaches a filamentous morphology.

Patterns of mPGES-1 and PGFS expression in the pig trophoblast have been recently determined (Waclawik et al., 2005). Profiles of mPGES-1 and PGFS mRNA and protein concentrations in trophoblasts/conceptuses correlated with changes in expression of these enzymes in endometrium. High expression of mPGES-1 in Day 10-12 conceptuses corresponds to elevated PGE ${ }_{2}$ concentrations in the uterine lumen and vein, and may be important in modulation of the $\mathrm{PGE}_{2}: \mathrm{PGF}_{2 \alpha}$ ratio necessary for the establishment of pregnancy.

\section{Conclusion}

Oestrogens and prostaglandins are critical components of the inhibition of luteolysis and main- 
tenance of $\mathrm{CL}$ function during early pregnancy in pigs (Fig. 1). Expression of oestrogen receptors in the uterus coincides with the secretion of oestrogen from the conceptus. Autocrine and paracrine dialogue between multiple conceptuses and uterine biological compounds and their receptors begins with a rapid morphological transformation from a spherical to filamentous form of trophoblast. Expression of many proteins (growth factors, integrins, inhibitors, etc.) that take part in trophoblast elongation or attachment to the uterine surface and in implantation coincides with oestrogen secretion by the conceptus (some of them are up-regulated by oestrogen). The determination of prostaglandins $E_{2}$ and $F_{2 \alpha}$ downstream enzymes (PGES and PGFS) in endometrium and spherical/elongated conceptuses highlights the integrated role of uterine/conceptus PGES in the inhibition of luteolysis by changing $P G E_{2}: P G F_{2 a}$ ratio. New emerging concepts also emphasise the autocrine and paracrine roles of luteal prostaglandins and oestrogen in $C L$ function. Luteotrophic $\mathrm{PGE}_{2}$ action in pigs probably requires oestrogen for inhibition of $\mathrm{PGE}_{2} 9$ oxoreductase in maternal and conceptus prostaglandins producing tissues. This may explain the inability to maintain luteal function following intrauterine infusions of $P G E_{2}$, as such treatment would stimulate PGF $_{2 \alpha}$ release by the intact pig uterus.

\section{Acknowledgement}

Some research reported in this chapter was supported by the State Committee for Scientific Research in Poland as a solicited project PBZ-KBN-084/P06/2002 and project 2 P06D041 26. M.M. Kaczmarek was awarded with Domestic Grant for Young Scientist from the Foundation for Polish Science.

\section{References}

Al-zi'abi MO, Watson ED and Fraser HM (2003) Angiogenesis and vascular endothelial growth factor expression in the equine corpus luteum Reproduction 25 259-270

Arosh JA, Banu SK, Kimmins S, Chapdelaine P, MacLaren LA and Fortier MA (2004) Effect of interfron-t on prostaglandin biosynthesis, transport, and signaling at the time of maternal recognition of pregnancy in cattle: evidence of polycrine actions of prostaglandin E2 Endocrinology 145 5280-5293

Baird A and Böhlen P (1991) Fibroblast Growth Factors I. In Peptide growth factors and their receptors pp 369-418 Eds MB Sporn and AB Roberts. SpringerVerlag, New York

Bazer FW and Thatcher WW (1977) Theory of maternal recognition of pregnancy in swine based on estrogen controlled endocrine versus exocrine secretion of prostaglandin F $2 \alpha$ by uterine endometrium Prostaglandins 14 397-401

Bazer FW, Geisert RD, Thatcher WW and Roberts RM (1982) The establishment and maintenance of preg. nancy. In Control of Pig Reproduction pp 227-252 Eds DJA Cole and GR Foxcroff. Butterworth Scientific, London

Blitek A and Ziecik A) (2005) Effect of luteinizing hormone on prostaglandins $\mathrm{F} 2 \alpha$ and E2 secretion by cultured porcine endometrial cells Reproduction 130 105-112

Boonyaprakob U, Gadsby JE, Hedgpeth V, Routh P and
Almond GW (2003) Expression and localization of vascular endothelial growth factor and its receptors in pig corpora lutea during the oestrous cycle Reproduction 126 393-405

Brigstock DR, Heap RB and Brown KD (1989) Polypeptide growth factors in uterine tissues and secretions Journal of Reproduction and Fertility 85 747-758

Brussow KP, Schneider F and Nurberg C (2001) Alternation of gonadotrophin and steroid hormone release and of ovarian function by a GnRH agonist in gilts Animal Reproduction Science 66 117-128

Burghardt RC, Johnson GA, Jaeger LA, Ka H, Garlow JE, Spencer TE and Bazer FW (2002) Integrins and extracellular matrix proteins at the maternal-foetal interface in domestic animals Cells and Tissue Organs 171 202-217

Carnahan KG, Prince BC and Mirando MA (1996) Exogenous oxytocin stimulates uterine secretion of prostaglandin $F 2 \alpha$ in cyclic and early pregnant swine Biology of Reproduction 55 838-843

Choy RB and Watkins WB (1988) Arginine vasopressin and oxytocin in the porcine corpus luteum Neuropeptides 11 119-123

Christenson LK, Farley DB, Anderson LH and Ford SP (1994) Luteal maintenance during early pregnancy in the pig: role for prostaglandin E2 Prostaglandins 4761.75

Conley Al and Ford SP (1989) Direct luteotrophic effect of oestradiol-17ß on pig corpora lutea Journal of Repro- 
duction and fertility 87 125-131

Corps AN, Brigstock DR, Littlewood CJ and Brown KD (1990) Receptors for epidermal growth factor and insulin-like growth factor-l on perimplantation trophoderm of the pig Development 110 221-227

Du Mesnil du Buisson F and Leglise PC (1963) Effet de l'hypophysectomie sue les corps jaunes de la truie. Resultatas preliminaires [Effect of the hypophysectomy on the porcine corpus luteum. Preliminary results.] C $r$ hebb Seanc Acad Sci Paris 257 261-263

Dusza L and Krzymowska H (1981) Plasma prolactin levels in sows during pregnancy, parturition and early lactation Journal of Reproduction and Fertility 61 131-134

Dusza L and Tilton JE (1990) Role of prolactin in the regulation of ovarian function in pigs fournal of $\mathrm{Re}$ production and Fertility (Suppl) $4033-45$

Dusza L, Tilton JE and Weigl RM (1986) Prolactin administration during futeal and follicular phase of the oestrous cycle of gilts fournal of Reproduction and Fertility $76519-525$

Flint APF, Saunders PTK and Ziecik AJ (1982) Blastocystendometrium interactions and their significance in embryonic mortality In Control of Pig Reproduction pp 253-275 Eds DJA Cole and GR Foxcroft. Butterworth Scientific, London

Gadsby JE, Balapure AK, Britt JH and Fitz TA (1990) Prostaglandin $F 2 \alpha$ receptors on enzyme-dissociated pig luteal cells throughout the estrous cycle Endocrinology 126 787-795

Gadsby JE, Lovdal JA, Britt JH and Fitz TA (1993) Prostaglandin $\mathrm{F} 2 \alpha$ receptor concentrations in corpora lutea of cycling, pregnant and pseudopregnant pigs. Biology of Reproduction $49604-608$

Garverick HA, Polge C and Flint APF (1982) Oestradiol administration raises luteal $\mathrm{LH}$ receptor levels in intact and hysteroctomized pigs fournal of Reproduction and Fertility 66 371-377

Geisert RD, Brenner RM, Moffatt RJ, Harney JP, Yellin $T$ and Bazer FW (1993) Changes in oestrogen receptor protein, mRNA expression and localization in the endometrium of cyclic and pregnant gilts Reproduction, Fertility and Development 5 247-260

Geisert RD, Renegar RH, Thatcher WW, Roberts RM and Bazer FW (1982) Establishment of pregnancy in the pig. I. Interrelationships between preimplantation development of the pig blastocyst and uterine endometrial secretions Biology of Reproduction 27 925-939

Geisert RD, Tratt TN, Bazer FW, Mayes IS and Watson GH (1994) Immunocytochemical localization and changes in endometrial progestin receptor protein during the porcine oestrous cycle and early pregnancy Reproduction, Fertility and Development 6749 . 760

Godkin JD and Doré JJE (1998) Transforming growth factor $B$ and the endometrium Reviews of Reproduction 3 1-6

Gray CA, Johnson GA, Bartol FF, Tarleton BJ, Wiley AA, Bazer FW and Spencer TE (2001) Developmental biology of uterine glands Biology of Reproduction $651311-1323$

Green ML, Simmen RCM and Simmen FA (1995) Developmental regulation of steroidogenic enzyme gene expression in the periimplantation porcine conceptus: a paracrine role for insulin-like growth factor-1 Endocrinology 136 3961-3970

Gregoraszczuk El. and Michas N (1999) Progesterone and estradiol secretion by porcine luteal cells is influenced by individual and combined treatment with prostaglandins $E_{2}$ and $F_{2 \alpha}$ throughout the estrus cycle Prostaglandins and other Lipid Mediators 57 231-241

Gross TS, Mirando MA, Young KH, Beers S, Bazer FW and Thatcher WW (1990) Reorientation of prostag landin $F$ secretion by calcium ionophore, estradiol, and prolactin in perfused porcine endometrium Endocrinology 127 637-642

Gupta A, Bazer FW and Jaeger LA (1996) Differential expression of beta transforming growth factors (TGFB1, TGFB2, and TCFB3) and their receptors (type 1 and type II) in peri-implantation porcine conceptuses Biology of Reproduction 55 796-802

Cupta A, Bazer FW and Jaeger LA (1997) Immunolocalization of acidic and basic fibroblast growth factors in porcine uterine and conceptus tissues Biology of Reproduction $561527-1536$

Gupta A, Ing NH, Bazer FW, Bustamante LS and jaeger LA (1998a) Beta Transforming growth factors (TGFß) at the porcine conceptus maternal interface. Part 1 : Expression of TGFß1, TGFß2, and TGFß3 messenger ribonucleic acids Biology of Reproduction 59 905-910

Gupta A, Dekaney ChM, Bazer FW, Madrigal MM and Jaeger LA (1998b) Beta Transforming growth factors (TCFB) at the porcine conceptus maternal interface. Part II: Uterine TGFß bioactivity and expression of immunoreactive TGFßs (TGFB1, TGFß2, and TGFß3) and their receptors (type $I$ and type II) Biology of Reproduction 59 911-917

Guthrie HD and Bolt DJ (1983) Changes in plasma estrogen, luteinizing hormone, follicle stimulating hormone and 13,14-dihydro-15-keto-prostaglandin F $2 \alpha$ during blockade of luteolysis in pigs after human chorionic gonadotropin treatment lournal of Animal Sciences 52 993-1000

Ka H, Jaeger LA, Johnson GA, Spencer TE and Bazer FW (2001) Keratinocyte growth factor is up-regulated by estrogen in the porcine uterine endometrium and functions in trophectoderm cell proliferation and differentiation Endocrinology 142 2303-2310

Ka H, Spencer TE, Johnson GA and Bazer FW (2000) Keratinocyte growth factor: expression by endometrial epithelia of the porcine uterus Biology of Reproduction 62 1772-1778

Kaczmarek M, Waclawik A, Kowalczyk AE, Blitek A and Ziecik AJ (2004) Expression and localization of vascular endothelial growth factor (VEGF) and its binding sites (Flt-1 and flk-1/KDR) in the porcine uterus during the oestrous cycle Reproduction in Domestic Animals 39287 
Kaczmarek MM, Schams D and Ziecik A] (2005) Role of vascular endothelial growth factor in ovarian physiology - an overview Reproductive Biology 5 111136

Kennedy TG, Brown KD and Vaughan T) (1994) Expression of genes for the epidermal growth factor receptor and its ligands in porcine oviduct and endometrium Biology of Reproduction 50 751-756

Ko Y, Choi I, Green ML, Simmen FA and Simmen RCM (1994) Transient expression of the cytochrome P450 aromatase gene in elongating porcine blastocysts is correlated with uterine insulin-like growth factor levels during peri-implantation development $\mathrm{Mo}$ lecular Reproduction and Development 37 1-11

Kotwica G, Dusza L, Ciereszko R, Okrasa S and Schams D (1990) Oxytocin plasma levels during spontaneous and cloprostenol-induced luteolysis in sows Animal Reproduction Sciences 22 109-119

Kotwica G, Franczak A, Okrasa S and Kotwica J (1999) Effect of an oxytocin antagonist on prostaglandin F2á secretion and the course of luteolysis in sows Acta Veterinaria Hungarica 47 249-262

Kraeling RR, Rampacek GB and Fiorello NA (1985) Inhibition of pregnancy with indomethacin in mature gilts and prepuberal gilts induced to ovulate Biology of Reproduction 32 105-110

Krzymowski T, Kotwica J and Stefanczyk-Krzymowska S (1990) Uterine and ovarian countercurrent pathways in the control of ovarian function in the pig Journal of Reproduction and Fertility (Suppl) 40 179-191

Krzymowski T, Kotwica J, Okrasa S, Doboszynska T and Ziecik A (1978) Luteal function in sows after unilateral PGF $2 \alpha$ infusion into the anterior uterine on different days of the oestrous cycle Journal of Reproduction and Fertility 54 21-27

Lee CY, Green ML, Simmen RC and Simmen FA (1998) Proteolysis of insulin-like growth factor-binding proteins (IGFBPs) within the pig uterine lumen associated with peri-implantation conceptus development Journal of Reproduction and Fertility $112369-377$

Lee KY and DeMayo FJ (2004) Animal models of implantation Reproduction 128 679-695

Lessey BA (2002) Adhesion molecules and implantation Journal of Reproductive Immunology 55 101-112

Letcher R, Simmen RC, Bazer FW and Simmen FA (1989) Insulin-like growth factor-1 expression during early conceptus development in the pig Biology of Reproduction 141 1143-1151

Ludwig TE, Sun B-C, Carnahan KG, Uzumcu M, Yelich JV, Geisert RD and Mirando MA (1998) Endometrial responsiveness to oxytocin during diestrus and early pregnancy in pigs is not controlled solely by changes in oxytocin receptor population density Biology of

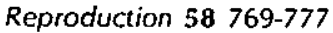

Neuvians TP, Berisha B and Schams D (2004) VEGF and FGF expression during induced luteolysis in the bovine corpus luteum Molecular Reproduction and Development 67 389.395

Okano A, Okuda K, Takahashi M and Schams D (1996) Oxytocin receptors in the porcine endometrium during the estrous cycle and early pregnancy Animal Reproduction Science 41 61-70

Okrasa SO, Tilton JE and Weigl RM (1985) Utero-ovarian venous concentrations of $\mathrm{PGF}_{2}$ and $\mathrm{PGF}_{2 a}$ following $\mathrm{PCE}_{2}$ intrauterine infusions Prostaglandins 30 851-856

Palejwala S, Tseng L, Wojtczuk A, Weiss G and Goldsmith LT (2002) Relaxin gene and protein expression and its regulation of procollagenase and vascular endothelial growth factor in human endometrial cells Biology of Reproduction 66 1743-1748

Prigent SA and Lemoine NR (1992) The type 1 (EGFRrelated) family of growth factor receptors and their ligands Progress in Growth Factor Research 4 1-24

Roberts AB, Heine UI, Flanders KC and Sporn MB (1990) Transforming growth factor- $B$. Major role in regulation of extracellular matrix Annals of the New York Academy of Sciences $580225-232$

Rosenkrans CF, Paria BC, Davis DL and Milliken G (1992) Synthesis of prostaglandins by pig blastocysts cultured in medium containing estradiol or catechol estrogen Prostaglandins 43 309-319

Schäfer-Somi S (2003) Cytokines during early pregnancy of mammals: a review Animal Reproduction Science 75 73-94

Simmen FA, Simmen RCM, Geisert RD, Martinat-Botte $F$, Bazer FW and Terqui $M$ (1992) Differential expression, during the estrous cycle and pre- and postimplantation conceptus development, of messenger ribonucleic acids encoding components of the pig uterine insulin-like growth factor system Endocrinology 130 1547-1556

Simmen RCM, Simmen FA, Ko Y and Bazer FW (1989) Differential growth factor content of uterine luminal fluids from Large White and prolific Meishan pigs during the estrous cycle and pregnancy lournal of Animal Science 67 1538-1545

Smith WL and Dewitt DL (1996) Prostaglandin endoperoxide $\mathrm{H}$ synthases- 1 and -2 Advances in Immunology 62 167-215

Song S, Lee CY, Green ML, Chung CS, Simmen RCM and Simmen FA (1996) The unique endometrial expression and genomic organization of the porcine ICFBP. 2 gene Molecular and Cellular Endocrinology 120 193-202

Spencer TE and Bazer FW (2002) Biology of progesterone action during pregnancy recognition and maintenance of pregnancy Frontiers in Bioscience $7 \mathrm{~d} 1879$. 1898

Spencer TE and Bazer FW (2004) Conceptus signals for establishment and maintenance of pregnancy Reproductive Biology and Endocrinology 2 49-62

Stefanczyk-Krzymowska S, Krzymowski T, Einer-Jensen N, Kaminski T and Kotwica J (1990) Local transfer of prostaglandin $\mathrm{F} 2 \alpha$ from the uterine lumen into the venous and arterial blood and into the uterine, mesometrial and ovarian tissue on Day 18 of pregnancy in the pig Animal Reproduction Science $23223-235$

Stepien A, Shemesh $M$ and Ziecik AJ (1999) Luteinizing hormone receptor kinetic and $\mathrm{LH}$-induced prostag- 
landin production throughout the oestrous cycle in porcine endometrium Reproduction Nutrition and Development $39663-674$

Stroband HW and Van der Lende T (1990) Embryonic and uterine development during early pregnancy in pigs Journal of Reproduction and Fertility (Suppl) $\mathbf{4 0}$ 261-277

Sukjumlong S, Persson E, Kaeoket K and Dalin A-E (2004) Immunohistochemical studies on oestrogen receptor alpha $(E R \alpha)$ and the proliferative marker Ki-67 in the sow uterus at oestrus and early pregnancy Reproduction in Domestic Animals 39 361-369

Szafranska $B$ and Ziecik A) (1989) Active and passive immunization against luteinizing hormone in pigs Acta Physiologica Hungarica 74 253-258

Szafranska B, Majewska M and Panasiewicz G (2004) Nglycodiversity of the Pregnancy-Associated Glycoprotein family (PAG) produced in vitro by trophoblast and trophectoderm explants during implantation, placentation and advanced pregnancy in the pig Reproductive Biology 4 67-89

Thoren S, Weinander R, Saha S, Jegerschold C, Pettersson PL, Samuelsson B, Hebert H, Hamberg $M$, Morgenstern R and Jakobsson PJ (2003) Human microsomal prostaglandin E-synthase: purification, functional characterization, and projection structure determination lournal of Biological Chemistry 278 22199-22209

Vaughan TJ, James PS, Pascall JC and Brown KD (1992) Expression of the genes for TCF $\alpha, E G F$ and the EGF receptor during early pig development Development 116 663-669

Waclawik A, Blitek A, Kaczmarek M and Ziecik AJ (2005) Expression patterns of mPGES-1 and PGFS in pig trophoblast. The $4 \mathrm{th}$ Joint Meeting of the UK Fertility Societies, Warwick, UK, 3-6 April

Waclawik A, Rahman NA, Rivero-Muller A, Brokken LJS, Watanabe K, Blitek A and Ziecik AJ (2004) Novel functional characterisation of expression of prostaglandin $F 2 \alpha$ synthase (PGFS) and microsomal prostaglandin E2 synthase (MPGES) in porcine oestrous cycle endometrium and in early pregnancy Reproduction Abstract Series 3113

Whiteaker S, Mirando MA, Becker WC and Hostetler CE (1994) Detection of functional oxytocin receptors on endometrium of pigs Biology of Reproduction 51 $92-98$
Wilson ME, Fahrenkrug SC, Smith TPL, Rohrer GA and Ford SP (2002) Differential expression of cyclooxygenase 2 around the time of elongation in the pig conceptus Animal Reproduction Science 71 229-237

Winther H, Ahmed A and Dantzer V (1999) Immunohistochemical localization of vascular endothelial growth factor (VEGF) and its two specific receptors, Flt- 1 and KDR, in the porcine placenta and nonpregnant uterus Placenta $2035-43$

Young KH, Kraeling RR and Bazer FW (1990) Effect of pregnancy and exogenous ovarian steroids in endometrial prolactin receptor ontogeny and uterine secretory response in pigs Biology of Reproduction $43592-599$

Żhang $Z$ and Davis DL (1991) Prostaglandin E and F2 $\alpha$ secretion by glandular and stromal cells of the pig endometrium in vitro: effect of estradiol-17ß, progesterone, and day of pregnancy Prostaglandins 421 $151-162$

Zhang Z, Krause M and Davis DL (1992) Epidermal growth factor receptors in porcine endometrium: binding characteristics and the regulation of prostaglandin $E$ and F2 alpha production Biology of Reproduction 46 932-936

Ziecik AJ (2002) Old, new and the newest concepts of inhibition of luteolysis during early pregnancy in pig Domestic Animal Endocrinology 23 265-275

Ziecik A\}, Bodek G, Ciereszko R, Stepien A and Kotwica $G$ (2001) Involvement of gonadotropins in induction of luteolysis in pigs Reproductive Biology $133-50$

Ziecik AJ, Jedlinska $M$ and Rzucidlo IS (1992) Effect of estradiol and progesterone on myometrial $\mathrm{LH} / \mathrm{hCC}$ receptors in pigs Acta Endocrinologica (Copenhagen) 127 185-188

Ziecik AJ, Stanchev PD and Tilton JE (1986) Evidence for the presence of luteinizing hormone/human chronic gonadotropin - binding sites in the porcine uterus Endocrinology 119 1159-1163

Ziecik A], Stepien A and Gawronska B (2000) Importance of endometrial $\mathrm{LH}$ receptor in induction of luteolysis and maternal recognition of pregnancy in the pig Reproduction in Domestic Animals 35190 192 